\title{
Assessment of serum zinc, selenium, and prolactin concentrations in critically ill children
}

This article was published in the following Dove Press journal:

Pediatric Health, Medicine and Therapeutics

4 April 2016

Number of times this article has been viewed

\author{
Farida $\mathrm{F}$ Negm' \\ Doaa R Soliman' \\ Enas S Ahmed ${ }^{2}$ \\ Rasha A Elmasry' \\ 'Department of Pediatrics, \\ ${ }^{2}$ Department of Clinical Pathology, \\ Faculty of Medicine, Benha University, \\ El-Kalyobia, Banha, Egypt
}

Background: In critically ill patients, there are reduced stores of antioxidants, which are associated with increased organ failure and even higher mortality. Trace elements, especially zinc and selenium, are the cornerstone of the antioxidant defense in acute systemic inflammatory response syndrome. Prolactin (PRL) is the counterregulatory stress hormone that prevents cortisol/stress-induced lymphocyte apoptosis. The aim of our study is to detect the serum levels of zinc, selenium, and PRL hormone as important immunomodulators in critically ill children and to investigate the relationship between these immunomodulators and the severity of illness.

Subjects and methods: This was a prospective study that included two groups; group 1: 50 critically ill children within 72 hours of intensive care unit admission, and group 2: 30 healthy children as controls. Blood samples were collected from the two groups for zinc, selenium, and PRL level measurement.

Results: Zinc and PRL levels were found to be decreased in critically ill children compared to control group, and these levels were inversely correlated with organ failure index and pediatric logistic organ dysfunction scores. Selenium levels were decreased in patients with sepsis and in patients with multiple organ failure.

Conclusion: Serum concentrations of zinc and PRL are generally low in critically ill children, with a greater decrease in patients with sepsis and in the presence of multiple organ failure. The levels of zinc and PRL are inversely correlated with severity of illness. Selenium levels were decreased in patients with sepsis and in patients with multiple organ failure.

Keywords: critically ill, intensive care, zinc, selenium, prolactin

\section{Introduction}

Critical illness or injury occurs when an impending or existing organ failure impairs the balance of oxygen and substrate supply and demand. Unless this state is prevented or reversed, cells of the body will sustain injury or die. ${ }^{1}$ Trace elements, especially zinc and selenium, are the cornerstone of the antioxidant defense in systemic inflammatory response syndrome. It is associated with redistribution of zinc and selenium to tissues involved in protein synthesis and immune cell proliferation, and this leads to decrease in their serum levels.

Zinc is an essential trace element that plays an important role in many biological functions; these include mucosal barrier function, innate and adaptive immunity, oxidative stress responses, and wound healing. Zinc deficiency causes loss of T- and B-cell maturation and also results in altered secretion of a number of cytokines. ${ }^{2}$

Selenium is an essential trace element involved in many immunological, endocrine, and antioxidant pathways. Selenium is important for maintenance of cellular
Correspondence: Rasha A Elmasry Department of Pediatrics, Faculty of Medicine, Benha University, El-Kalyobia, Banha I35I I, Egypt

Tel +20 I06 II 00994

Email Rasha.masry80@yahoo.com Dovepress http://dx.doi.org/10.2147/PHMT.S99191
Pediatric Health, Medicine and Therapeutics 2016:7 17-23

(c) (1) (8) ( 2016 Negm et al. This work is published and licensed by Dove Medical Press Limited. The full terms of this license are avalabble at https://wwr.doverpess.com/terms. 
membrane integrity. In addition, it aids in thyroid hormone production. $^{3}$

Prolactin (PRL) is a protein hormone as well as a cytokine that is synthesized and secreted from specialized cells of the anterior pituitary gland, named lactotrophs. It is also synthesized in many extrapituitary tissues such as cells of the immune system (macrophages, natural killer cells, and T- and B-lymphocytes). PRL acts by stimulating the secretion of other cytokines and the expression of cytokine receptors, which indicates that PRL may influence the immune system. ${ }^{4}$ Stress-induced lymphocyte apoptosis is thought to be mediated, in part, through the adrenocorticotropic hormonecortisol axis. PRL is a counterregulatory stress hormone, which prevents cortisol/stress-induced lymphocyte apoptosis through increased Bcl-2 production. ${ }^{5}$

In our study, we aimed at detecting serum levels of zinc, selenium, and PRL in patients in the pediatric intensive care unit (PICU) and at investigating the relationship between these immunomodulators and the severity of illness.

\section{Subjects and methods}

This study was carried out on 50 critically ill children (23 males and 27 females), aged 1-18 years, within 72 hours of PICU admission in Benha University Hospital (30 asymptomatic children were taken as controls [15 males and 15 females]). The study was approved by the Ethics Committee of Benha University of Medicine after obtaining consent from the parents of the enrolled children. Patients using immunomodulators, those with traumatic injuries, and readmitted cases were excluded.

The cases were subjected to complete history taking, including history of chronic illness and chronic medication use, primary admission diagnosis, and current medications. Vital signs and body weight were checked. General examination including activity and conscious level of patients, signs of distress or dehydration, as well as systemic examination were also carried out. Presence of infection or sepsis was checked according to the Center for Disease Control and Prevention criteria. ${ }^{6}$ Severity of illness was detected using organ failure index (OFI) and pediatric logistic organ dysfunction (PELOD) scores. ${ }^{7}$

Approximately 1-7 mL of blood was collected via venipuncture in metal-free tubes and allowed to clot for 30 minutes at room temperature, and then centrifuged at 3,000 rpm for 30 minutes. Serum was checked for hemolysis by visual inspection and separated into three aliquots for zinc, selenium, and PRL assessment. It was stored frozen until analysis.

\section{Zinc determination}

Zinc level was determined using colorimetric assay based on the chelation of zinc present in the sample by adding zincon (2-caboxy-2'hydroxy-5-sulphoformazyl-benzene) in the reagent at alkaline $\mathrm{pH}$. The formation of this complex was measured at a wavelength of $610 \mathrm{~nm} .^{8}$

\section{Selenium determination}

Selenium level was determination using colorimetric assay by mixing equal volumes of Dye 2 and Buffer 3 immediately before use in disposable tubes. Glasswares were rinsed with dilute hydrochloric acid and distilled water. Working reagent and samples were mixed and incubated for 2 minutes at room temperature, and then absorbance values of standard and sample were read at $520 \mathrm{~nm}$ against the reagent blank within 30 minutes. ${ }^{9}$

\section{PRL determination}

The PRL quantitative test is based on a solid-phase enzyme-linked immunosorbent assay. The assay system utilized one mouse monoclonal anti-PRL antibody for solid-phase (micro titer wells) immobilization and another in the antibody-enzyme (horseradish peroxidase) conjugate solution. The test sample was allowed to react simultaneously with the antibodies, resulting in PRL molecules being sandwiched between the solid phase and enzyme-linked antibodies. After 45 minutes of incubation at room temperature, the wells were washed with water to remove unbound, labeled antibodies. A solution of tetramethylbenzidine (TMB) reagent was added and the mixture was incubated at room temperature for 20 minutes, resulting in development of a color. The color development was stopped with the addition of stop solution, which changed the color was changed to yellow, and the developed color was measured spectrophotometrically at $450 \mathrm{~nm}$. The concentration of PRL is directly proportional to the color intensity of the test sample. ${ }^{10}$

\section{Statistical analysis}

The collected data were tabulated and analyzed using SPSS version 16 software (SPSS Inc, Chicago, IL, USA). Categorical data were presented as number and percentages, while quantitative data were expressed as median, interquartile range, and range. Spearman's correlation coefficient $(\rho)$, and Student's $t$-test, and Mann-Whitney $U$-test were used as tests of significance. The accepted level of significance in this work was stated at $0.05(P<0.05$ was considered significant). ${ }^{11}$ 


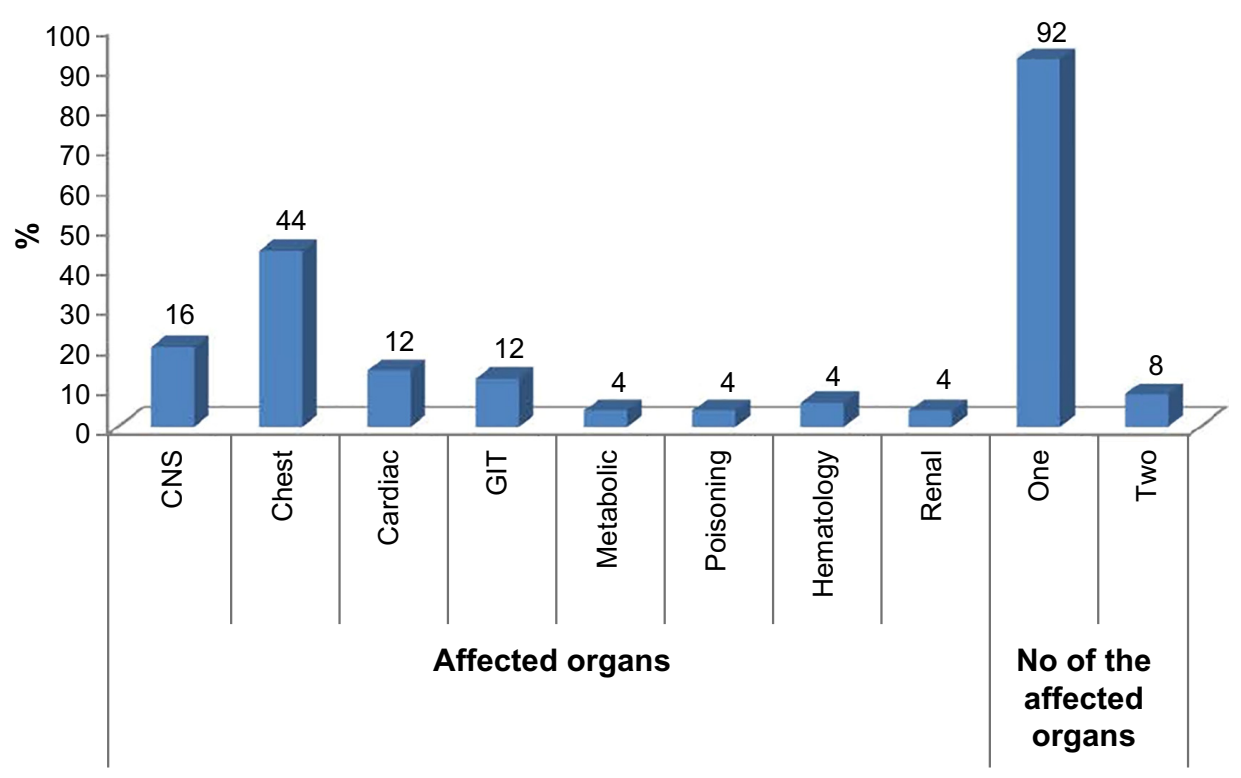

Figure I Affected organs in the study group.

Abbreviations: CNS, central nervous system; GIT, gastrointestinal tract.

\section{Results}

In our study, patients with chest problems represented the majority of cases $(44.0 \%)$, followed by those with central nervous system $(16.0 \%)$, and then cardiac and gastrointestinal tract conditions (12\%) (Figure 1).

There was a highly statistically significant difference $(P<0.001)$ between zinc levels in cases (median is $81.0 \mathrm{mg} / \mathrm{dl}$ ) and controls (median is $186.0 \mathrm{mg} / \mathrm{dl}$ ). There was no difference in selenium levels between cases (median is $143.0 \mathrm{ng} / \mathrm{mL}$ ) and controls (median is $142.0 \mathrm{ng} / \mathrm{mL}$ ). There was a statistically significant difference $(P=0.004)$ between PRL levels in cases (median is $12.3 \mathrm{ng} / \mathrm{mL}$ ) and controls (median is $44.0 \mathrm{ng} / \mathrm{mL}$ ) (Table 1).

Patients in whom two organs were affected have levels of zinc (median is $56.0 \mathrm{mg} / \mathrm{dL}$ ) lower than that in patients in whom one organ was affected (median is $82.0 \mathrm{mg} / \mathrm{dL}$ ). Also, patients in whom two organs were affected have selenium levels (median is $133.0 \mathrm{ng} / \mathrm{mL}$ ) lower than that in patients in whom one-organ was affected (median is $143.0 \mathrm{ng} / \mathrm{mL}$ ). PRL levels were lower (median is $16.2 \mathrm{ng} / \mathrm{mL}$ ) in patients with two organs affected compared with those in whom one organ was affected (median is $21.0 \mathrm{ng} / \mathrm{mL}$ ) (Table 2). Levels of zinc, selenium, and PRL in patients with sepsis (medians were $77.0 \mathrm{mg} / \mathrm{dL}, 142.0 \mathrm{ng} / \mathrm{mL}$, and $18.2 \mathrm{ng} / \mathrm{mL}$, respectively) were lower than that in patients without sepsis (medians were $81.0 \mathrm{mg} / \mathrm{dL}, 160.0 \mathrm{ng} / \mathrm{mL}$, and $30.2 \mathrm{ng} / \mathrm{mL}$, respectively) (Table 3 ).

In patients with chronic illness, the mean serum levels of zinc $(56.49 \pm 12.52 \mathrm{mg} / \mathrm{dL})$ were less than that $(83.66 \pm 25.58 \mathrm{mg} / \mathrm{dL})$ in patients without chronic illness. There was no difference in selenium levels between patients with chronic illness (mean: $137.05 \pm 31.51 \mathrm{ng} / \mathrm{mL}$ ) and patients without chronic illness (mean: $139.25 \pm 42.15 \mathrm{ng} / \mathrm{mL}$ ). Mean PRL levels in patients with chronic illness $(23.62 \pm 8.95 \mathrm{ng} / \mathrm{mL})$ were less than that in patients without chronic illness (35.24 $\pm 15.63 \mathrm{ng} / \mathrm{mL}$ ) (Figure 2).

Zinc was significantly inversely correlated with OFI score $(P=0.047)$, and PRL was significantly inversely correlated with OFI score $(P=0.049)$. There was no correlation between selenium and OFI score (Table 4).

Table I Comparison of regarding zinc, selenium, and PRL levels between the study groups

\begin{tabular}{|c|c|c|c|c|c|c|c|c|c|c|}
\hline \multirow[t]{2}{*}{ Variable } & \multicolumn{4}{|c|}{ Cases $(n=50)$} & \multicolumn{4}{|c|}{ Controls $(n=30)$} & \multirow{2}{*}{$\begin{array}{l}\text { Z of MWU } \\
\text { test }\end{array}$} & \multirow[t]{2}{*}{$P$-value } \\
\hline & Median & IQR & Min & Max & Median & IQR & Min & Max & & \\
\hline Zinc (mg/dL) & 81.0 & $39.7-104.0$ & 1.4 & 226 & 186.0 & |47.7-2 | 7.0 & 53 & 293 & 6.68 & $<0.00 \mathrm{I}(\mathrm{HS})$ \\
\hline Selenium (ng/mL) & 143.0 & $102.7-\mid 70.7$ & 53 & 211 & 142.0 & I I4.2-164.0 & 60 & 198 & 0.25 & 0.8 \\
\hline PRL (ng/mL) & 12.3 & $2.35-40.7$ & 0.07 & 224.4 & 44.0 & $6.08-161.6$ & 0.1 & 224.4 & 2.84 & $0.004(S)$ \\
\hline
\end{tabular}

Abbreviations: HS, highly significant; IQR, interquartile range; Max, maximum; Min, minimum; MWU, Mann-Whitney U; PRL, prolactin; S, significant. 
Table 2 Levels of serum zinc, selenium, and PRL according to the number of the affected organs

\begin{tabular}{|c|c|c|c|c|c|c|c|c|}
\hline \multirow[t]{2}{*}{ Variable } & \multicolumn{3}{|c|}{ One organ affected $(\mathrm{N}=46)$} & \multicolumn{3}{|c|}{ Two organs affected $(\mathrm{N}=4)$} & \multirow[t]{2}{*}{$Z$ of MWU test } & \multirow[t]{2}{*}{$P$-value } \\
\hline & Median & IQR & Range & Median & IQR & Range & & \\
\hline Zinc (mg/dL) & 82.0 & $39.7-104.2$ & $1.4-226$ & 56.0 & $23-81.5$ & $15-87$ & 1.09 & 0.27 \\
\hline Selenium $(\mathrm{ng} / \mathrm{mL})$ & 143.0 & $109.7-162.5$ & $53-211$ & 133.0 & $90.7-176.7$ & $90-178$ & 0.14 & 0.88 \\
\hline PRL (ng/mL) & 21.0 & $1.79-46.9$ & $0.07-224.4$ & 16.2 & $12.4-24.5$ & II.7-26.6 & 0.57 & 0.56 \\
\hline
\end{tabular}

Abbreviations: IQR, interquartile range; MWU, Mann-Whitney U; PRL, prolactin.

Zinc was significantly inversely correlated with PELOD score $(P=0.026)$, and PRL was significantly inversely correlated with PELOD score $(P=0.039)$. There was no correlation between selenium and PELOD score (Table 5).

\section{Discussion}

The provision of nutritional supplements with the ability to affect cells of the immune system is a promising therapy that may help to maintain immune system efficacy and prevent infection. ${ }^{12}$ Three natural immunomodulators important for lymphocyte health are zinc, selenium, and PRL. ${ }^{13}$

In this study, we detected the serum levels of zinc, selenium, and PRL in critically ill children in the PICU and investigated their relationship to the severity of illness.

Compared with the healthy control subjects, children in the ICU generally had significantly lower serum concentration of zinc. This agrees with the findings of Cvijanovich et al, ${ }^{14}$ who found low plasma zinc level in his study conducted in 20 critically ill patients, and with that of Linko et al, ${ }^{15}$ who detected low serum zinc in $95.8 \%$ of critically ill patients.

In this study, we found no difference in selenium level between critically ill children and controls. This is consistent with the findings of Heyland et al's ${ }^{16}$ randomized, blinded trial conducted in North American patients; they did not find low plasma selenium concentration, which was observed in European and South American patients. Therefore, they concluded that racial factors may affect selenium level.

In contrast to our study, Heidemann et $a{ }^{17}$ and Dylewski et al ${ }^{18}$ reported selenium deficiency in critically ill patients. This different result may be explained because the increased selenium losses in ICU patients are unlikely to account for the marked reductions in plasma selenium concentrations, and the findings suggest there may be significant changes in the distribution of body selenium during critical illness. ${ }^{19}$

Our study showed significant difference in PRL levels between critically ill children and controls. In support of this observation, Heidemann et $\mathrm{al}^{17}$ found low serum level of PRL in PICU patients early after ICU admission. Also, Felmet et $\mathrm{al}^{20}$ reported that critical illness induces hypoprolactinemia. On the contrary, the results of Kumar et al's ${ }^{21}$ study differed from our results, as they found that PRL hormone increases in stressful situations.

We observed that the more the number of organs affected, the lesser the serum level of zinc, selenium, and PRL.

The results of Besecker et al's ${ }^{22}$ study were in accordance with our observation, as they found that zinc deficiency leads to more organ dysfunction. The results of our study were found to be in agreement with that of Kate et al's ${ }^{20}$ study, which showed that hypoprolactinemia was more common in children with multiple organ failure.

These observations were also supported by Manzanares et $\mathrm{al}^{23}$ who found that selenium and glutathione peroxidase levels significantly decreased in patients with multiple organ dysfunction system. Sakr et al ${ }^{24}$ also reported that selenium decreases more in patients with a higher degree of organ dysfunction.

We observed that in the presence of sepsis, there was a greater decrease in serum levels of zinc, selenium, and PRL in ICU patients.

This finding is in accordance with that of Bhatnagar et al, ${ }^{25}$ who concluded that zinc supplementation reduces the risk of treatment failure in bacterial infection; Karakonstantakis et al, ${ }^{26}$ who found that zinc acts as negative acute-phase

Table 3 Levels of serum zinc, selenium, and PRL according to presence of sepsis

\begin{tabular}{|c|c|c|c|c|c|c|c|c|}
\hline \multirow[t]{2}{*}{ Variable } & \multicolumn{3}{|c|}{ No sepsis $(\mathrm{N}=34)$} & \multicolumn{3}{|c|}{ Sepsis $(\mathrm{N}=16)$} & \multirow{2}{*}{$\begin{array}{l}Z \text { of MWU } \\
\text { test }\end{array}$} & \multirow[t]{2}{*}{$P$-value } \\
\hline & Median & IQR & Range & Median & IQR & Range & & \\
\hline Zinc (mg/dL) & 81.0 & $42.2-105.7$ & I.4-226 & 77 & $26.7-91.5$ & $4.2-119$ & 1.09 & 0.27 \\
\hline Selenium (ng/mL) & 160.0 & $113.5-177.0$ & $53-211$ & 142 & $98.7-158.7$ & $77-177$ & 0.42 & 0.67 \\
\hline PRL (ng/mL) & 30.1 & I.14-40.7 & $0.07-224.4$ & 18.2 & $4.5-44.8$ & $0.48-192$ & 0.33 & 0.74 \\
\hline
\end{tabular}

Abbreviations: IQR, interquartile range; MWU, Mann-Whitney U; PRL, prolactin. 


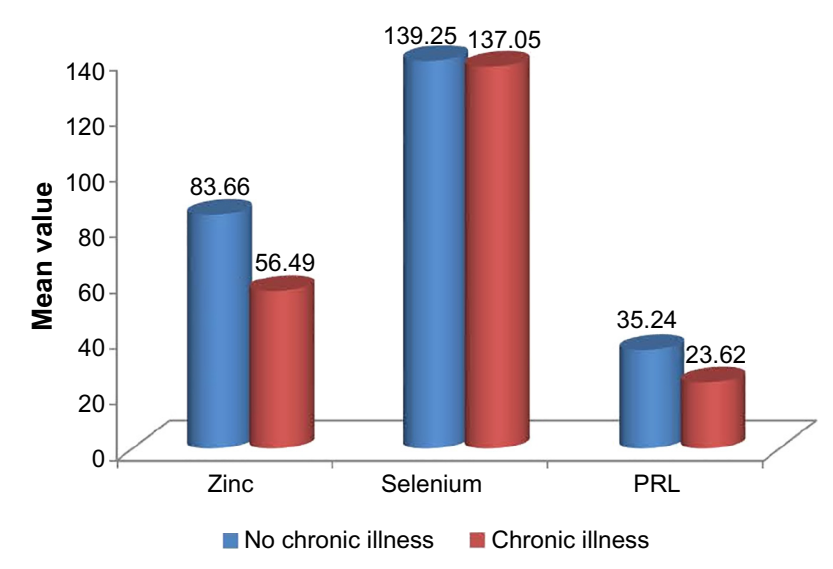

Figure 2 Zinc, selenium, and PRL levels in patients according to presence of chronic illness.

Abbreviation: PRL, prolactin.

reactant and is correlated with intensity of inflammatory stimulus; and Besecker et al, ${ }^{27}$ who observed decreased zinc level during critical illness in the presence of sepsis.

Kumar and Singhi demonstrated decreased plasma selenium level in critically ill patients, especially those with septic shock. Also, Duncan et $\mathrm{al}^{28}$ found that plasma selenium decreased further with increased intensity of inflammatory response.

Yavagal et $\mathrm{al}^{29}$ reported that metoclopramide (PRL secratalogue) delayed time of onset of nosocomial pneumonia by $50 \%$ but did not affect mortality. On the contrary, Lesur et a ${ }^{30}$ found that in critically ill patients, PRL levels and cortisol were significantly higher in septic shock patients, and Maxime et $\mathrm{al}^{31}$ observed hyperprolactinemia in patients with sepsis.

We observed that zinc concentration decreased more in patients with chronic illness. This finding was supported by the studies of Navarro-Alarcon et $\mathrm{al}^{32}$ and Cabré et al, ${ }^{33}$ which reported low zinc levels in patients with chronic illness.

Also, PRL concentration decreased more in the presence of chronic illness. Opalinska et al's ${ }^{34}$ study demonstrates a different result, as they found that the presence of an elevated PRL level is a common hormonal change in patients with chronic diseases. The results of Hou et al's $\mathrm{s}^{35}$ study are also contrary to our finding.

Table 4 Correlation between OFI and serum zinc, selenium, and PRL among the studied cases

\begin{tabular}{lll}
\hline With & OFI & \\
\cline { 2 - 3 } & $\rho$ & P-value \\
\hline Zinc $(\mathrm{mg} / \mathrm{dL})$ & -0.23 I & $0.047(\mathrm{~S})$ \\
Selenium $(\mathrm{ng} / \mathrm{mL})$ & 0.107 & 0.46 \\
PRL $(\mathrm{ng} / \mathrm{mL})$ & -0.280 & $0.049(\mathrm{~S})$ \\
\hline
\end{tabular}

Abbreviations: OFI, organ failure index; PRL, prolactin; S, significant.
Table 5 Correlation between PELOD and serum zinc, selenium, and PRL among the studied cases

\begin{tabular}{lll}
\hline With & PELOD & \\
\cline { 2 - 3 } & $\rho$ & P-value \\
\hline Zinc $(\mathrm{mg} / \mathrm{dL})$ & -0.157 & $0.026(\mathrm{~S})$ \\
Selenium $(\mathrm{ng} / \mathrm{mL})$ & 0.114 & 0.43 \\
PRL $(\mathrm{ng} / \mathrm{mL})$ & -0.271 & $0.039(\mathrm{~S})$ \\
\hline
\end{tabular}

Abbreviations: PELOD, pediatric logistic organ dysfunction; PRL, prolactin; S, significant.

Yoshimura et a ${ }^{36}$ reported that patients with chronic renal failure have lower level of selenium than patients without chronic illness. But our data did not show any difference regarding selenium level between patients with chronic illness and patients without chronic illness.

In the current study, zinc is inversely correlated with OFI and PELOD scores. This is consistent with the findings of Cvijanovich et al ${ }^{14}$ who reported that zinc levels correlated inversely with degree of organ failure, and with the findings of Linko et al, ${ }^{15}$ who found an association between low serum zinc and organ failure scores.

We observed negative relationship between PRL and scores of illness severity (OFI and PELOD). This is similar to the findings of Cui et al. ${ }^{37}$

Our results showed that there is no correlation between selenium and OFI and PELOD scores, which is in accordance with the results of Avenell et al. ${ }^{38}$ In contrast to our results, Manzanares et al, ${ }^{23}$ Sakr et al, ${ }^{24}$ and Vincent and Forceville ${ }^{39}$ showed a significant negative correlation between plasma selenium level and severity of illness scores.

Heidemann et al, ${ }^{17}$ in their study of 293 critically ill children, concluded that serum concentrations of zinc, selenium, and PRL are often low in critically ill children early after PICU admission.

\section{Limitation}

In this study, assessment of tissue levels and body stores of zinc and selenium was not performed. Also, the correlation between these immunomodulator concentrations and severity of illness being affected by many other factors has to be taken into consideration.

\section{Conclusion}

Serum concentrations of zinc and PRL are generally decreased in critically ill children, with more pronounced decrease in the presence of organ dysfunction/failure and during sepsis. Zinc and PRL levels are correlated with severity of illness. We did not find any difference in selenium levels between critical cases and controls, but it decreases in patients 
with sepsis and in patients with more than one organ failure. Therefore, we recommend supplementation of these trace elements to deficient, critically ill patients.

\section{Disclosure}

The authors report no conflicts of interest in this work.

\section{References}

1. Frankel LR, DiCarlo JV. Pediatric intensive care. In: Bernstein D, Shelov SP, editors. Pediatrics for Medical Students. 2nd ed. Philadelphia, PA: Lippincott Williams and Wilkins; 2003:541.

2. Kumar S, Singh S. Zinc and selenium in critically ill children. Where do they stand? IPP. 2014;2(1):297-306.

3. Khannaa P, Agarwala A, Dalim KB, Mahesh KA. Trace elements in critical illness. $J$ Endocrinol Metab. 2011;1(2):57-63.

4. Garner JS. Guideline for isolation precautions in hospitals. The Hospital Infection Control Practices Advisory Committee. Infect Control Hosp Epidemiol. 1996;17(1):53-80.

5. Freeman ME, Kanyicska B, Lerant A, Nagy G. Prolactin: structure, function, and regulation of secretion. Physiol Rev. 2000;80(4): $1523-1631$.

6. Garner JS, Jarvis WR, Emori TG, et al. CDC definitions of nosocomial infections. In: Olmsted RN, editor. APIC Infection Control and Applied Epidemiology: Principles and Practice. St Louis, MO: Mosby; 1996:A1-A20.

7. Leteurtre S, Martinot A, Duhamel A, et al. Validation of the pediatric logistic organ dysfunction (PELOD) score: prospective, observational, multicentre study. Lancet. 2003;362:192-197.

8. Hayakawa R. [Determination of zinc]. Jap J Toxic Environ Health. 1961;8:14-18. Japanese.

9. Teitz NW. Clinical Guide to Laboratory Tests. Philadelphia, PA: W B Sauders Co; 1983.

10. Uotila M, Ruoslahti E, Engavall E. Two-site sandwich enzyme immunoassay with monoclonal antibodies to human alpha-fetoprotein. J Immunol Methods. 1981;42:11-15.

11. Khothari CR. Research Methodology: Methods and Techniques. New Delhi, India: New Age International; 2004.

12. Mizock BA. Immunonutrition and critical illness. An update. Nutrition. 2010;26:701-707.

13. Carcillo JA, Dean JM, Holubkov R, et al. Eunice Kennedy Shriver National Institute of Child Health and Human Development (NICHD) Collaborative Pediatric Critical Care Research Network (CPCCRN): the randomized comparative pediatric critical illness stress-induced immune suppression (CRISIS) prevention trial. Pediatr Crit Care Med. 2012;13:165-173.

14. Cvijanovich NZ, King JC, Flori HR, Gildengorin G, Wong HR. Zinc homeostasis in pediatric critical illness. Pediatr Crit Care Med. 2009;10(1):29-34.

15. Linko R, Karlsson S, Pettila V, et al. Serum zinc in critically ill adult patients with acute respiratory failure. Acta Anaesthesiol Scand. 2011;55(5):615-621.

16. Heyland D, Muscedere J, Wischmeyer PE, et al; Canadian Critical Care Trials Group. A randomized trial of glutamine and antioxidants in critically ill patients. $N$ Engl J Med. 2013;368:1489-1497.

17. Heidemann SM, Holubkov R, Meert KL, et al. Baseline serum concentrations of zinc, selenium, and prolactin in critically ill children. Pediatr Crit Care Med. 2013;14(4):e202-e206.

18. Dylewski ML, Bender JC, Smith AM, et al. The selenium status of pediatric patients with burn injuries. J Trauma. 2010;69:584-588.

19. Hawker FH, Stewart PM, Snitch PJ. Effects of acute illness on selenium homeostasis. Crit Care Med. (Hayakawa R. Jap J. Toxic Environ. Health 8,14-18(1961).1990;18(4):442-446.

20. Felmet KA, Hall MW, Clark RS, Jaffe R, Carcillo JA. Prolonged lymphopenia, lymphoid depletion, and hypoprolactinemia in children with nosocomial sepsis and multiple organ failure. $J$ Immunol. 2005; 174:3765-3772.
21. Kumar KV, Kapoor U, Kalia R, Chandra NS, Singh P, Nangia R. Low triiodothyronine predicts mortality in critically ill patients. Indian $J$ Endocrinol Metab. 2013;17(2):285-288.

22. Besecker BY, Exline MC, Hollyfield J, et al. A comparison of zinc metabolism, inflammation, and disease severity in critically ill infected and noninfected adults early after intensive care unit admission. Am J Clin Nutr. 2011;93:1356-1364.

23. Manzanares W, Biestro A, Galusso F, et al. Serum selenium and glutathione peroxidase-3 activity: biomarkers of systemic inflammation in the critically ill? Intensive Care Med. 2009;35(5):882-889.

24. SakrY, Reinhart K, Bloos F, et al. Time course and relationship between plasma selenium concentrations, systemic inflammatory response, sepsis, and multiorgan failure. Br J Anaesth. 2007;98(6):775-784.

25. Bhatnagar S, Wadhwa N, Aneja S, et al. Zinc as adjunct treatment in infants aged between 7 and 120 days with probable bacterial infection: a randomised, double-blind, placebo-controlled trial. Lancet. 2012;379(9831):2072-2078.

26. Karakonstantakis T, Papassotiriou I, Sergounioti A, et al. Evaluation of zinc and selenium alterations in children with acute infections. Correlation with markers of inflammation. Interv Med Appl Sci. 2012;4(1):15-20.

27. Besecker B, Bao S, Bohacova B, et al. The human zinc transporter SLC39A8 (Zip8) is critical in zinc-mediated cytoprotection in lung epithelia. Am J Physiol Lung Cell Mol Physiol. 2008;294: L1127-L1136.

28. Duncan A, Talwar D, McMillan DC, et al. Quantitative data on the magnitude of systemic inflammatory response and its effect on micronutrient status based on plasma measurements. Am J Clin Nutr. 2012;95:64-71.

29. Yavagal DR, Karnad DR, Oak JL. Metoclopramide for preventing pneumonia in critically ill patients receiving enteral tube feeding: a randomized controlled trial. Crit Care Med. 2000;28(5):1408-1411.

30. Lesur O, Roussy J, Chagnon F, et al. "Proven infection-related sepsis induces a differential stress response early after ICU admission". Crit Care. 2010;14(4):R131.

31. Maxime V, Siami S, Annane D. Metabolism modulators in sepsis. The abnormal pituitary response. Crit Care Med. 2007;35(9):S596-S601.

32. Navarro-Alarcon M, Reyes-PérezA, Lopez-Garcia H, Palomares-Bayo M, Olalla-Herrera M, Lopez-Martinez MC. Longitudinal study of serum zinc and copper levels in hemodialysis patients and their relation to biochemical markers. Biol Trace Elem Res. 2006;113(3):209-222.

33. Cabré M, Camps J, Paternáin JL, et al. Time-course of changes in hepatic lipid peroxidation and glutathione metabolism in rats with carbon tetrachloride- induced cirrhosis. Clin Exp Pharmacol Physiol. 2000;27:694-699.

34. Opalinska-Ciszek E, Niemczyk S, Matuszkiewicz-Rowinska J. Prolactin (PRL), free thyroid hormones (fT4), (fT3) and testosterone (TTE) level in men with chronic heart failure. Pol Arch Med Wewn. 2005;113:320-325.

35. Hou SH, Grossman S, Molitch ME. Hyperprolactinemia in patients with renal insufficiency and chronic renal failure requiring hemodialysis or chronic ambulatory peritoneal dialysis. Am J Kidney Dis. 1985;6(4):245-249.

36. Yoshimura S, Suemizu H, Nomoto Y, et al. Plasma glutathione peroxidase deficiency caused by renal dysfunction. Nephron. 1996;73:207-211.

37. Cui N, Liu DW, Wang H, et al. Early changes in function of hypothalamic-pituitary-target gland axis in patients with severe sepsis and septic shock. Zhongguo Wei Zhong Bing Ji Jiu Yi Xue. 2007;19(6):332-335. Chinese.

38. Avenell A, Noble DW, Barr J, Engelhardt T. Selenium supplementation for critically ill adults. Cochrane Database Syst Rev. 2004;18(4):CD003703.

39. Vincent JL, Forceville X. Critically elucidating the role of selenium. Curr Opin Anaesthesiol. 2008;21:148-154. 
Pediatric Health, Medicine and Therapeutics

Dovepress

\section{Publish your work in this journal}

Pediatric Health, Medicine and Therapeutics is an international, peerreviewed, open access journal publishing original research, reports, editorials, reviews and commentaries. All aspects of health maintenance, preventative measures and disease treatment interventions are addressed within the journal. Practitioners from all disciplines are invited to submit their work as well as healthcare researchers and patient support groups. The manuscript management system is completely online and includes a very quick and fair peer-review system. Visit http://www.dovepress.com/ testimonials.php to read real quotes from published authors.

Submit your manuscript here: http://www.dovepress.com/pediatric-health-medicine-and-therapeutics-journal 